Review

\title{
Brugada Syndrome: Oligogenic or Mendelian Disease?
}

\author{
Michelle M. Monasky ${ }^{\dagger}$, Emanuele Micaglio ${ }^{\dagger}$, Giuseppe Ciconte and Carlo Pappone * \\ Arrhythmology Department, IRCCS Policlinico San Donato, Piazza E. Malan 1, San Donato Milanese, \\ 20097 Milan, Italy; michelle.monasky@grupposandonato.it (M.M.M.); \\ emanuele.micaglio@grupposandonato.it (E.M.); g.ciconte@gmail.com (G.C.) \\ * Correspondence: carlo.pappone@af-ablation.org; Tel.: +39-0252-774260; Fax: +39-0252-774306 \\ † These authors contributed equally to this work.
}

Received: 12 February 2020; Accepted: 28 February 2020; Published: 1 March 2020

\begin{abstract}
Brugada syndrome (BrS) is diagnosed by a coved-type ST-segment elevation in the right precordial leads on the electrocardiogram (ECG), and it is associated with an increased risk of sudden cardiac death (SCD) compared to the general population. Although BrS is considered a genetic disease, its molecular mechanism remains elusive in about $70-85 \%$ of clinically-confirmed cases. Variants occurring in at least 26 different genes have been previously considered causative, although the causative effect of all but the SCN5A gene has been recently challenged, due to the lack of systematic, evidence-based evaluations, such as a variant's frequency among the general population, family segregation analyses, and functional studies. Also, variants within a particular gene can be associated with an array of different phenotypes, even within the same family, preventing a clear genotype-phenotype correlation. Moreover, an emerging concept is that a single mutation may not be enough to cause the BrS phenotype, due to the increasing number of common variants now thought to be clinically relevant. Thus, not only the complete list of genes causative of the BrS phenotype remains to be determined, but also the interplay between rare and common multiple variants. This is particularly true for some common polymorphisms whose roles have been recently re-evaluated by outstanding works, including considering for the first time ever a polygenic risk score derived from the heterozygous state for both common and rare variants. The more common a certain variant is, the less impact this variant might have on heart function. We are aware that further studies are warranted to validate a polygenic risk score, because there is no mutated gene that connects all, or even a majority, of BrS cases. For the same reason, it is currently impossible to create animal and cell line genetic models that represent all BrS cases, which would enable the expansion of studies of this syndrome. Thus, the best model at this point is the human patient population. Further studies should first aim to uncover genetic variants within individuals, as well as to collect family segregation data to identify potential genetic causes of BrS.
\end{abstract}

Keywords: Brugada syndrome; sudden cardiac death; genetic testing; mutation; SCN5A; sodium channel; arrhythmia; channelopathy; segregation analysis; functional studies

\section{Introduction}

Brugada syndrome $(\mathrm{BrS})$ is a cardiac arrhythmia associated with an increased risk of sudden cardiac death (SCD) compared to the general population, diagnosed by the presence of a type $1 \mathrm{BrS}$ pattern on the electrocardiogram (ECG), namely a coved-type ST-segment elevation in the right precordial leads [1,2]. This type 1 pattern may occur spontaneously, intermittently, and in a dynamic way, often in relation with many environmental factors, including drugs, illicit drugs, alcohol, fever, and heavy meals. 
In patients in whom a spontaneous type 1 pattern has not been observed, a pharmacological challenge may be performed to unmask the pattern. However, it is imperative that these procedures are performed in specialized centers, due to the associated risks [3]. Current guidelines state that, for BrS, implantable cardioverter defibrillator (ICD) placement is the only proven effective therapy for the prevention of SCD [4], although recent studies have highlighted the potential of radiofrequency ablation of the arrhythmogenic substrate [5].

Although the prevalence has been described as 1:2000 in Western Europe and the USA and 1:500 in Southeast Asia [6], the true prevalence of BrS is unknown, due to the lack of symptoms for even decades in many people and the challenges involved in diagnosis. In Southeast Asia, BrS seems to affect almost exclusively male adults [7]. Pooled analyses indicated that a spontaneous type 1 ECG is an independent risk factor for SCD in males, but not in females, and that male patients are at higher risk of arrhythmic events [8,9]. However, $\mathrm{BrS}$ is found throughout the world and in both genders, to whom studies have shown it is transmitted equally [5] as an autosomal dominant disease with incomplete penetrance [10-12]. However, a few recent articles suggest some possible alternative mechanisms of inheritance, such as autosomal recessive [13] or X linked [14]. Due to the increasing number of variants, both common and rare, found in BrS patients, perhaps an oligogenic model should replace the traditional Mendelian model for BrS [15].

\section{The Challenges Surrounding BrS Genetics}

To the best of current knowledge, $\mathrm{BrS}$ is still considered a genetic disease, although the genetics remain elusive in about $70-85 \%$ of clinically-confirmed cases, in spite of the widespread use of the next-generation sequencing (NGS) technique with a high coverage (at least 100×). Variants occurring in at least 26 different genes (Table 1) have been previously considered causative [16], although the causative effect of all but the $S C N 5 A$ gene has been recently challenged [17]. In fact, many genetic tests reporting variants in these genes return results with uncertain significance. The source of such uncertainty is often the aforementioned idea that all $\mathrm{BrS}$ cases are inherited with a Mendelian autosomal dominant mechanism. This idea prevents the geneticist from considering a possible cumulative role of both common and rare genetic variants, because, according to the previous hypothesis, there must be one and only one mutation. Thus, the role of cumulative genetic variants within the same individual in the causative effect of disease expression is currently a source of debate [18]. Further complicating matters, different variants within a particular gene can be responsible for an array of different phenotypes [19], even within the same family $[20,21]$. These situations make many genotype-phenotype correlations very difficult.

A study by Risgaard and colleagues [22] evaluated the presence in the general population of previously BrS-associated heterozygous variants in several genes, namely CACNA1C, CACNA2D1, $C A C N B 2, G P D 1 L, K C N D 3, K C N H 2, S C N 1 B b, S C N 3 B, K C N J 8$, and SCN5A. The authors concluded that variants in these genes are common in the general population, occurring at a rate of 1:23. This article reflects the idea of $\mathrm{BrS}$ as a Mendalian disease and used in silico predictions to define the pathogenicity of certain variants. However, in silico predictions cannot be relied upon as a single tool to predict pathogenicity [23]. Nevertheless, this study laid the groundwork in understanding the prevalence of these variants in the general population, which could be used by later groups to develop polygenic risk scores, taking into account other studies that suggest that BrS is very likely a multigenic disorder, rather than a Mendelian condition. Another study by the same group [24] evaluating the clinical picture in patients harboring previously reported BrS-associated genetic variants in the genes $C A C N A 1 C$, CACNA2D1, CACNB2, KCNH2, PKP2, SCN10A, SCN1B, SCN3B, SCN5A, and TRPM4 found that the mean J-point elevation in V1 and V2 were within normal limits, and there was no difference in reported incidences of syncope, ventricular arrhythmias, or overall mortality, compared to non-carriers of the variants, concluding that the variants are not the monogenic cause of BrS. However, in that study, patients were not tested for BrS with a provocative drug, and so the spontaneous J-point elevations reported may be misleading. In fact, in that study, no significant differences in J-point elevation 
were found even between carriers and non-carriers of SCN5A variants. Then, another genome-wide association study published by the same group the next year [25] reported an association between the single nucleotide polymorphism (SNP) rs6800541 in the SCN10A gene with an increase in J-point elevation compared to wildtype in both lead V1 and V2, while the SNPs studied in the genes SCN5A and HEY 2 did not significantly affect the J-point. The SNPs in all three genes HEY2, SCN5A, and SCN10A were associated with significant changes in PR interval and QRS duration. The SCN5A and SCN10A variants studied were different from those in the prior [24] study. The rs9388451 genetic locus adjacent to the HEY2 gene was also associated with ventricular fibrillation and cardiac arrest [25]. It is interesting that, again, none of the SNPs studied, including that in the SCN5A gene, were found to be predisposing to syncope, atrial fibrillation, or total mortality. However, again, the electrocardiographic data may be misleading, as in the prior study, because it relies on spontaneously collected electrocardiograms, which are well known to be unreliable in the diagnosis of BrS, even for about $80 \%$ of patients who have experienced cardiac arrest or syncope because of documented ventricular fibrillation $[5,26]$. A study by a different group [27] studying the same genetic variation (rs9388451) adjacent to the HEY2 gene reported its role in the alteration of ion channel expression across the cardiac ventricular wall and its possible association with BrS. Thus, further understanding of the various individual variants within the diverse alleged BrS-related genes is necessary [28].

The search for other BrS-related genes is complicated by several factors. First, as described above, $\mathrm{BrS}$ appears to not be a Mendelian disease, but rather an oligogenic disease, which is affected by several loci, each of which is influenced by a huge number of environmental factors. Second, entire genome analysis is extremely costly, and even if it is performed, data from several patients need to be pulled to begin to understand which variants may be causative of BrS versus which variants may be modulators of the syndrome or not related at all to BrS.

To the best of our knowledge, variants in at least 26 different genes have been previously indicated as causative of BrS, but many genetic factors, such as polymorphisms [29], and non-genetic factors, such as fever, are known to alter the disease expression. Likely, BrS should no longer be described as a single disorder, but rather defined as a group of disorders clumped together only by their common alteration in the ECG [2,30], all characterized by vastly different clinical pictures and patterns of inheritance [20].

BrS can share some genetic mutations with other forms of arrhythmias, and this is much more common than had been expected [31]. The same variant can apparently result in different phenotypes even among family members [15,32,33]. And finally, a further source of complexity in discovering other BrS-related genes is that the same BrS phenotype can be caused by variants even in different genes encoding proteins with completely different functions. Variants in some of those genes can even result in overlap syndromes, and, in fact, overlap between BrS and other heart diseases, such as hypertrophic cardiomyopathy [34] and arrhythmogenic right ventricular (RV) dysplasia/cardiomyopathy (ARVD/C) [35], has been described. The limit of genotype-phenotype correlation among these mutations is the incomplete knowledge about the real mechanism of BrS. Today, for instance, it is well understood that the so called "trigger situations" like alcohol, fever, high temperature, drugs and illicit drugs can modulate sodium channel function in the heart conduction system [36], eliciting the BrS ECG pattern even in asymptomatic individuals harboring heterozygous variants and/or mutations in the SCN5A gene. An excellent article suggested that, in BrS patients, a certain kind of "metabolic impairment" might exist, and this impairment affects alcohol metabolism [37]. On the other hand, when studying modifiers of the SCN5A gene, it is poorly understood how a mutation in a structural gene, encoding for instance a desmosomal protein, can affect channel function enough to cause BrS in the absence of a mutation or variant in the SCN5A gene. Variants in genes encoding for desmosomal proteins, such as JUP, DSP, PKP2, and DSG2, have been associated with ARVD/C and dilated cardiomyopathy (DCM), both of which are associated with SCD [38]. Desmosomal proteins, such as plakophilin-2 (encoded by PKP2) and desmoglein-2 (encoded by DSG2), have been described to interact with $\mathrm{Na}_{V} 1.5$ [39] and implicated as a possible cause of 
$\mathrm{BrS}$ and ARVD/C [40]. However, the role of these desmosomal proteins in BrS pathology is still under debate.

Since SCD can be the first manifestation of BrS, it is imperative to identify even completely asymptomatic patients with this syndrome, who may not realize the need to visit a physician. It would be extremely useful to have a more powerful genetic test, which could be used on a wide basis, to diagnose the syndrome without drug challenge tests and to stratify the risk of future arrhythmic events [41].

Table 1. Genes currently associated with Brugada syndrome.

\begin{tabular}{|c|c|c|c|}
\hline & $\begin{array}{l}\text { Pubmed Results as of October } \\
\text { 16, } 2019 \text { for "Brugada Syndrome } \\
\text { AND (Gene)" }\end{array}$ & $\begin{array}{l}\text { Examples of Family Segregation } \\
\text { Studies Performed for BrS? }\end{array}$ & $\begin{array}{l}\text { Examples of Functional Studies } \\
\text { Performed for BrS? }\end{array}$ \\
\hline SCN5A & 742 & {$[16,19,28,42,43]$} & [44] \\
\hline SCN10A & 26 & {$[45,46]$} & [45-47] \\
\hline SCN1B & 36 & $\begin{array}{l}\text { [48]: but suggests SCN1B is not a } \\
\text { monogenic cause of BrS }\end{array}$ & {$[49,50](S C N 1 B b)$} \\
\hline SCN2B & 11 & N/A & [51] \\
\hline SCN3B & 17 & N/A & [52] \\
\hline RANGRF & 4 & N/A & [53-55] \\
\hline GPD1L & 11 & N/A & [56] \\
\hline CACNA1C & 30 & N/A & $\mathrm{N} / \mathrm{A}$ \\
\hline CACNA2D1 & 6 & N/A & N/A \\
\hline CACNB2 & 15 & N/A & [57] \\
\hline TRPM4 & 14 & $\mathrm{~N} / \mathrm{A}$ & [58] \\
\hline PKP2 & 18 & [59] & [59] \\
\hline ABCC9 & 6 & $\mathrm{~N} / \mathrm{A}$ & [60] \\
\hline $\mathrm{HCN} 4$ & 10 & N/A & [61] \\
\hline KCND2 & 4 & N/A & $\mathrm{N} / \mathrm{A}$ \\
\hline KCND3 & 20 & N/A & {$[62,63]$} \\
\hline KCNE3 & 11 & N/A & [64] \\
\hline KCNE5 & 6 & $\mathrm{~N} / \mathrm{A}$ & [65] \\
\hline KCNJ8 & 9 & N/A & [66] \\
\hline TPM1 & 1 & [34] & N/A \\
\hline MYBPC3 & 4 & $\mathrm{~N} / \mathrm{A}$ & $\mathrm{N} / \mathrm{A}$ \\
\hline SEMA3A & 3 & $\mathrm{~N} / \mathrm{A}$ & [67] \\
\hline FGF12 & 2 & $\mathrm{~N} / \mathrm{A}$ & $\mathrm{N} / \mathrm{A}$ \\
\hline SLMAP & 4 & N/A & [68] \\
\hline HEY2 & 129 & N/A & {$[18,69-71]$} \\
\hline LRRC10 & 1 & N/A & N/A \\
\hline
\end{tabular}

\section{Sodium Channel Mutations}

The most commonly mutated gene in BrS is $S C N 5 A$, occurring in about $15-30 \%$ of cases [72]. Consequently, the $\mathrm{Na}_{\mathrm{V}} 1.5$ encoded protein is the best known in $\mathrm{BrS}$ studies. A multi-study analysis consisting of $1892 \mathrm{BrS}$ patients concluded that symptomatic patients at the time of diagnosis or electrophysiological study (EPS) with SCN5A variants were at higher risk of arrhythmic events compared to symptomatic SCN5A-negative patients [73]. Also, some articles have described the possible modulation of $S C N 5 A$ mutations by common polymorphisms [74]. A common genetic factor that unifies all SCN5A-related cases has yet to be found, possibly because BrS is only a particular ECG pattern caused by multiple factors [75] and not by a single mutation. In fact, the normal QRS complex in a human ECG is regulated by several genes, some of them already studied as possible candidates for BrS and, more generally, for familial arrhythmic disorders [76]. Interestingly, this article [76] proposed $S C N 10 A$ as the major QRS regulatory gene and, about eight years later, our research group demonstrated that a comparison between $S C N 5 A$ and SCN10A Brugada patients is possible [77]. 
The idea that BrS is only a particular ECG pattern caused by multiple factors and not by a single mutation is supported by the finding that sodium channel blockers do not provoke the BrS ECG pattern in healthy individuals or in all SCN5A mutation carriers [75]. Several studies have reported a role for common variants in BrS, particularly in sodium channel-related genes. Genome-wide association studies are particularly important for identifying common modifier variants that alter disease susceptibility. Along these lines, a genome-wide association study identified an association with BrS for two alleles on chromosome 3 and one allele on chromosome 6, located closest to the genes SCN5A, SCN10A, and HEY2, respectively [18]. This demonstrates that predisposition to BrS can occur because of the presence of common genetic variants in sodium channel genes or the transcriptional regulator HEY2. Furthermore, association data from genome-wide association studies used to calculate weighted polygenic risk scores have been explored as predictive tools to anticipate the results of ajmaline challenges, with a study by Tadros and colleagues [78] describing the association between polygenic risk scores and the slowing of cardiac conduction with ajmaline. Thus, the role of common variants in disease susceptibility must be considered, and is much more important than previously recognized.

Routinely, in silico predictions are used to ascertain the likelihood of the pathogenicity of a particular variant. However, these analyses tools are often unreliable or result in an uncertain significance of a particular variant [77]. Thus, family segregation analysis and functional studies are still necessary to understand the likelihood of pathogenicity of a particular variant, even after the performance of in silico studies.

Given the uncertain significance of many variants found in BrS patients, including the variability between people with the same variant and the lack of functional studies in most cases, recent studies have focused on understanding the phenotypic effect of individual variants within the SCN5A gene $[16,19,28,42,43,77,79,80]$, as well as the search for additional genes involved in this multi-causative pathology $[32,77,81-83]$. As previously mentioned, one such study demonstrated the similarity in phenotype between patients harboring SCN10A variants, as opposed to SCN5A variants, including personal history of cardiac arrest/syncope, spontaneous BrS electrocardiogram pattern, family history of sudden death, and arrhythmic substrate [77]. This is consistent with functional studies performed in human-induced pluripotent stem cell-derived cardiomyocytes, in which single-cell phenotype features of BrS were seen in cells from a patient harboring the variants NM_006514.3:c.3803G $>$ A and NM_006514.3:c.3749G $>$ A in the SCN10A gene [47]. In a multicenter study in which candidate genes were sequenced, including SCN10A, the study concluded that the common rs6795970 in the SCN10A gene was strongly associated with $\mathrm{BrS}$ and resulted in a loss of function of $\mathrm{Na}_{\mathrm{V}} 1.8$, as did rare $S C N 10 \mathrm{~A}$ variants found in patients, although co-segregation studies did not always support the functional study findings [45]. Thus, the study concluded that their data do not support a strong role for SCN10A variants as monogenic causes of BrS. However, a study by Hu and colleagues [46] identified SCN10A as a major susceptibility gene for BrS, identifying SCN10A mutations in 25 out of 150 probands (17\%), suggesting an important role for this gene in BrS. The importance of this gene is supported by studies about the influence of the SCN10A gene in both cardiac conduction [84] and the autonomic nervous system [85].

The sodium channel genes $S C N 1 B, S C N 2 B$, and $S C N 3 B$ have been associated with BrS and are included in BrS diagnostic panels, although their role is disputed [17]. A study by Watanabe and colleagues has described the SCN1B gene in association with both cardiac conduction disease and Brugada syndrome [86]. Described in case reports [87,88], the R214Q variation in $S C N 1 B b$ has been reported as a functional polymorphism that may serve as a modifier of the substrate responsible for $\mathrm{BrS}$ via a combined loss of function of sodium channel current and gain of function of transient outward potassium current [87]. In another study, the IVS3+2996(TTA) 8 allele was described as an SCN1B polymorphism that may make middle-aged, male Japanese more susceptible to BrS, while not causing BrS by itself [89]. Furthermore, a study by Yuan and colleagues [49] identified the H162P mutation in the $S C N 1 B b$ gene in a BrS patient, and, extrapolating that mutation to in vitro studies, found that this mutation reduces the action potential amplitude and conduction velocity, creating an 
increased risk of ventricular arrhythmia. However, genotype-phenotype correlations in families with $B r S$ and reported pathogenic $S C N 1 B$ or $S C N 1 B b$ variants are lacking [48]. Additionally, studies report identifying variants in the $S C N 1 B$ gene in BrS patients with low prevalence [90] and low evidence of pathogenicity [17].

Described in a case report, the $S C N 2 B$ gene was identified as a new candidate gene for BrS, reducing sodium channel current density and $\mathrm{Na}_{\mathrm{V}} 1.5$ cell surface expression [51]. SCN2B deletion in mice results in ventricular and atrial arrhythmias [91]. Likewise, an SCN3B variant described by $\mathrm{Hu}$ and colleagues in a case study was suggested to lead to a loss of transport and functional expression of the $\mathrm{hNa}_{\mathrm{V}} 1.5$ protein, resulting in a BrS phenotype [92]. Similarly, a report by Ishikawa and colleagues identified the V110I variant in the SCN3B gene in three out of 178 Japanese BrS patients, and demonstrated that this variant leads to decreased cell surface expression of $\mathrm{Na}_{V} 1.5$ and reduced sodium current [52]. However, segregation analysis is lacking for each of these genes, and further studies should be performed to further understand their effects [17].

Sodium channel function can be affected by factors outside of genetic mutations in the gene coding for the channel itself. In one study investigating the consequences of $\mathrm{K}_{\mathrm{V}} 4.3$ overexpression on $\mathrm{Na}_{\mathrm{V}} 1.5$ current and consequent sodium channel availability, the authors concluded that the current of the $\mathrm{Na}_{\mathrm{V}} 1.5$ protein was directly impacted by several factors, including the gain-of-function of the $\mathrm{K}_{\mathrm{V}} 4.3$ protein encoded for by the KCND3 gene [62]. It has been suggested that post-translational modifications, such as a defect in the splicing process [93] or trafficking [94,95], or a modification in phosphorylation, methylation, or acetylation [96], could explain alterations in the function of the channel encoded by SCN5A in the absence of mutations in this gene itself. Also, the predicted phenotypic effect of a particular variant should take into consideration that ancestry can affect the pathogenicity of a particular variant [97]. Thus, there are several factors that can contribute to channel function, or dysfunction, other than mutations in the $S C N 5 A$ gene itself that encodes for the $\mathrm{Na}_{\mathrm{V}} 1.5$ protein.

Another gene currently in the BrS diagnostic panel is RANGRF [98], the RAN Guanine Nucleotide Release Factor, also called MOG1, which regulates the expression and function of the $\mathrm{Na}_{\mathrm{V}} 1.5$ cardiac sodium channel in humans by enhancing the expression of $\mathrm{Na}_{\mathrm{V}} 1.5$ at the cell membrane, increasing sodium current densities [53-55]. The GPD1L gene, which encodes glycerol-3-phosphate dehydrogenase-1 like protein and is currently also included in BrS diagnostic panels [98], also regulates $\mathrm{Na}_{V}$ 1.5. Variants in GPD1L have been described as responsible for a loss of enzymatic function resulting in glycerol-3-phosphate PKC-dependent phosphorylation of SCN5A at serine 1503, prominently decreasing sodium current [56]. NAD ${ }^{+}$has been reported to possibly counteract the effect of PKC by activating PKA [99]. However, the causative effect of variants in each of these genes has also been disputed [17].

Some centers now consider the LRRC10 gene to be associated with BrS [100]. This gene encodes for the Heart-Restricted Leucine-Rich Repeat Protein and has been described as a transcriptional target of Nkx2.5, which regulates the ion channel proteins encoded by the SCN5A, CACNA1C, and KCNH2 genes [101].

These studies show that the function of the $\mathrm{Na}_{\mathrm{V}} 1.5$ protein may be affected in diverse ways, either by direct variants in the $S C N 5 A$ gene encoding for $\mathrm{Na}_{\mathrm{V}} 1.5$, or by variants in genes encoding for proteins that interact with $\mathrm{Na}_{\mathrm{V}} 1.5$, modulating its function in a transient way. However, further studies are required to clarify the role of variants in each of these genes in the expression of the BrS phenotype.

\section{Calcium Channel Mutations}

Given the important role of calcium for the cardiac action potential, it is very likely that the real role of calcium currents in BrS is underrated [2]. Calcium is central to excitation-contraction coupling, linking the electrical signal detected by ECG that defines BrS to the mechanical dysfunction, including ventricular fibrillation and reduced contractility, seen in BrS. Importantly, the BrS phenotype is modulated by non-genetic factors, such as an increase in vagal tone or body temperature, factors that are known to display altered calcium signaling. Furthermore, the BrS phenotype can be reversed 
in patients by the drug isoproterenol, known for its $\beta$-adrenergic stimulatory effects, increasing calcium transport through L-type calcium channels, ryanodine receptors, and SERCA (via relief of phospholamban inhibition). Therefore, the function of calcium channels, including in the presence of post-translational modifications, should be investigated in BrS [2].

Currently included in BrS diagnostic panels are the calcium-related genes CACNA1C, CACNA2D1, CACNB2, TRPM4, and PKP2 [98]. The CACNA1C, CACNA2D1, and CACNB2 genes encode for the voltage-dependent L-type calcium channel subunits alpha $1 C$, alpha $2 /$ delta subunit 1 , and beta 2 , respectively. Variants in $C A C N A 1 C$ have been reported to account for approximately $6.6 \%$ of $\mathrm{BrS}$ cases, while $C A C N B 2 b$ variants account for about $4.8 \%$, and $C A C N A 2 D 1$ variants are rare $[102,103]$.

Variants in the TRPM4 gene account for about $6 \%$ of BrS cases [58] and encode the Transient Receptor Potential Cation Channel Subfamily M Member 4, a calcium-activated nonselective ion channel that transports monovalent cations, such as $\mathrm{Na}^{+}$and $\mathrm{K}^{+}$, across the membrane, increasing its activity in response to an increased intracellular calcium concentration, but without significant permeation of $\mathrm{Ca}^{2+}$ itself [104]. This might be one reason why it should be regarded carefully before being considered a real BrS gene. In spite of that, it is included in BrS diagnostic panels [98], described as potentially causative of BrS type 1 in an autosomal recessive, rather than an autosomal dominant, manner [13]. The TRPM4 gene encodes for the protein Transient receptor potential cation channel subfamily M member 4, also called Calcium-Activated Non-Selective Cation Channel 1, which is a calcium-activated, but calcium-impermeable, nonselective cation channel [105]. Pathological variants in this gene have been implicated in complete heart block, ventricular tachycardia, and BrS [106], and this gene also plays a role in hypertrophy [107]. TRPM4 gene protein products can influence the inotropic effect of $\beta$-adrenergic stimulation [105]. The half-life of its protein products have been reportedly altered in patients with complete heart block or ventricular arrhythmias [106]. Despite this, the role of the TRPM4 gene in BrS must be interpreted carefully, as systematic, evidence-based evaluations for its causative effects are still lacking [17].

The PKP2 gene, encoding plakophilin-2, found in desmosomes within the intercalated discs, links cadherins to intermediate filaments in the cytoskeleton, and has been specifically reviewed previously [108]. This gene was described in one report as being associated with approximately $2.5 \%$ of BrS cases in which patients did not harbor mutations in the BrS-related genes SCN5A, CACNA1C, GPD1L, or MOG1 [59].

In a PKP2 knockout mouse model, RYR2, ANK2, CACNA1C, and TRDN expression were reduced, as well as protein levels of calsequestrin-2, leading to disruption of intracellular calcium homeostasis and isoproterenol-induced arrhythmias because of loss of cell-cell communication [109]. However, the role of variants in this gene is disputed, as family segregation studies are lacking $[17,110]$.

\section{Potassium Channel Mutations}

Variants in genes encoding potassium channels have been associated with BrS in a few cases, but their incidence needs to be assessed because not all cardiogenetics centers include these genes in the NGS panel.

The $A B C C 9$ gene encodes for ATP Binding Cassette Subfamily C Member 9 transport proteins that carry various molecules across cell membranes, and variants in this gene have been reported to be associated with $4-5 \%$ of BrS cases [103].

The HCN4 gene encodes the Hyperpolarization Activated Cyclic Nucleotide Gated Potassium Channel 4, important for pacing the heart rate. Variants in the HCN4 gene are rarely associated with BrS patients [103]. The KCND2 and KCND3 genes encode the proteins Potassium Voltage-Gated Channel Subfamily D Member 2 and 3, respectively, and they play a role in heart rate regulation. Variants in these genes are rarely associated with BrS patients [103].

The genes KCNE3 and KCNE5 encode the proteins Potassium Voltage-Gated Channel Subfamily E Regulatory Subunit 3 and 5, respectively. Variants in either are rarely associated with BrS [103,111]. Despite this, they are still included in BrS diagnostic panels in many cardiogenetics centers [98]. 
The KCNH2 gene, encoding the protein Potassium Voltage-Gated Channel Subfamily H Member 2, has been described in association with approximately $1-2 \%$ of BrS cases [103], and is included in diagnostic panels [98]. Finally, the KCNJ8 gene, encoding the protein Potassium Voltage-Gated Channel Subfamily J Member 8, is rarely associated with BrS [103], although included in diagnostic panels [98]. Thus, although potassium channel variants are rarely found in association with BrS, and family segregation and functional studies are lacking [17], these genes are still routinely screened for variants in BrS patients.

\section{Sarcomeropathies}

While BrS has been classically regarded as a channelopathy caused by variants in genes encoding for channel proteins on the cellular membrane, recent studies have identified non-channel genes associated with the syndrome. Also, although BrS was for a long time considered a "purely electrical disease without structural abnormalities", recent studies have now reported epicardial surface and interstitial fibrosis, reduced gap junction expression, and increased collagen, as well as reduced contractility and RV structural abnormalities consistent with ARVC involving predominantly the RV anterior wall $[2,35,112]$. Along these lines, a study by Mango et al. described the finding of a mutation in the TPM1 gene, encoding the sarcomeric $\alpha$-tropomyosin, as causative of an overlap syndrome resulting in both hypertrophic cardiomyopathy and BrS phenotypes [34]. While further studies are necessary to confirm the role of TPM1 variants in BrS, this study could imply that BrS may not always originate as variations in the genes encoding for channel proteins, but may also result from sarcomeric gene variants that are important in the regulation of calcium homeostasis [82]. In fact, it has been extensively studied that alterations in sarcomeric proteins can lead to arrhythmias and sudden death [113-115]. In one recent report, MYBPC3 was associated for the first time with $\mathrm{BrS}$ [32], while many other sarcomeric variants have been associated with sudden death [115]. Thus, while BrS is classically considered a channelopathy, recent studies have demonstrated an overlap with cardiomyopathy characteristics, including structural abnormalities and findings in alterations in genes that encode for sarcomeric proteins.

\section{Other Genes}

The gene SEMA3A is involved in neuronal development and function, and it is currently included in some BrS diagnostic panels [98]. A PubMed search for "SEMA3A AND Brugada syndrome" on October 7, 2019 resulted in only three results: a meta-analysis in which only two variants in SEMA3A were identified out of 128 publications reporting 43 genes potentially associated with BrS [116], a review [98], and functional studies on cardiomyocytes derived from human-induced pluripotent stem cells [67]. In fact, a recent study contested the validity of the SEMA3A gene being included in BrS diagnostic panels [17]. Similarly, while the gene FGF12 is currently included in diagnostic panels [98], a PubMed search for "FGF12 AND Brugada syndrome" on October 7, 2019 resulted in only two results: a review [98] and a study in which a variant in FGF12 was found in a single patient [117]. Finally, while the gene SLMAP is currently included in diagnostic panels [98], a PubMed search for "SLMAP AND Brugada syndrome" on October 7, 2019 resulted in only four results: a review [98], functional studies in transgenic mice [68], a meta-analysis that described finding two variants among 128 publications reporting 42 genes potentially associated with BrS [116], and the study to which the meta-analysis seems to be referring [118]. The SLMAP gene has been recently disputed as causative of $\mathrm{BrS}$, lacking systematic, evidence-based evaluations as to the association between this gene and $\mathrm{BrS}$, while in this same study, the genes SEMA3A and FGF12 did not even meet the criteria to be evaluated to be determined whether they could be potentially causative of BrS [17].

\section{Discussion}

Although the majority of BrS cases remain undisputedly molecularly unconfirmed, BrS is still considered by many to be a Mendelian disease. Clinical assessments support that $\mathrm{BrS}$ is an inheritable 
syndrome, but genotype-phenotype data to determine which specific variants are responsible for the disease is generally lacking. Questions remain as to which genes are involved and what is the real contribution of every variant found by NGS. Although many studies have focused on sodium channel mutations, alterations in genes that encode for sodium channels are not found in about two-thirds of cases, a fact which highlights the need to expand the research beyond the sodium channel gene $S C N 5 A$. It has to be mentioned also that other mechanisms can be involved in BrS pathogenesis that could indirectly affect the sodium channel function, which do not originate as genetic mutations in the sodium channel gene itself.

BrS has a complex pathogenesis based on a dysfunction of ion channels: the fast upstroke in phase 0 of the cardiac action potential depends on the $\mathrm{Na}_{\mathrm{V}} 1.5$ protein that works as a channel for sodium cations $\left(\mathrm{Na}^{2+}\right)$ [103]. Variants in the SCN5A gene believed to cause BrS are thought to work by resulting in a slowing of conduction in the heart. Among these variants, some have been studied functionally, revealing that a loss of function in $\mathrm{Na}_{\mathrm{V}} 1.5$ can occur through different mechanisms, including decreased expression of the sodium channel protein $\left(\mathrm{Na}_{\mathrm{V}} 1.5\right)$ in the sarcolemma [119], production of a non-functional channel [33], or alteration in gating properties, such as delayed activation, earlier inactivation, faster inactivation, enhanced slow inactivation, and delayed recovery of $\mathrm{Na}_{\mathrm{V}} 1.5$ after inactivation $[120,121]$.

There is emerging evidence about the role of CNVs involving the $S C N 5 \mathrm{~A}$ gene as a cause of BrS. For instance, Mademont-Soler and colleagues described a duplication (from exon 15 to 28 of SCN5A) demonstrated with MLPA (multiplex ligation-dependent probe amplification) that was not detected in six other first-grade relatives, all negative to Flecainide challenge test [122]. Later, Sonoda and coworkers described, using the same technique, four BrS patients harboring CNVs in the SCN5A gene (3 deletion and 1 duplication) [123]. These are examples of a possible new mechanism for BrS, and further studies are needed to clarify the clinical significance of CNVs in the SCN5A gene in BrS patients.

While some BrS cases can be explained by either SCN5A variants or CNVs, not all BrS cases can be justified by a functional impairment in the sodium channel $\mathrm{Na}_{\mathrm{V}} 1.5$. Other sodium, calcium, or potassium channels can be involved in the disease's pathogenesis. In particular, the role of calcium channels is an emerging field in which many groups are still studying all over the world [124,125].

One of the most interesting results recently reached by Abdelsayed and colleagues is that SCN5A heterozygous mutated embryonic kidney cells show differences in calcium sensitivity [126]. Thus, it could be possible that elevated cytosolic calcium concentrations (common, for example, during physical exercise) exacerbate the BrS phenotype when the syndrome is caused by a heterozygous SCN5A mutation. Another important study reported a complex BrS inheritance in a family harboring SCN5A and CACNA1C mutations [127].

While it seems relevant that the sodium channel plays a pivotal role in the syndrome, it remains unclear how genetic and non-genetic factors can influence the function of the sodium channel, or what other channel proteins or non-channel proteins may be involved. Whole genome studies may be useful to identify new candidate genes, which could then be further assessed using family segregation and functional studies. Complications surrounding whole genome studies include an extraordinary number of incidental findings, and thus a large number of patients are needed to determine which variants may be related to BrS and which variants are most likely incidental findings. Thus, it is important for researchers to form collaborations with other institutions to increase the study patient population, as well as to combine data from individuals within the same family for family segregation analysis when family members have been followed at different institutions. Obtaining family segregation data may include asking patients to put healthcare providers in contact with family members, asking the family to send medical records, and contacting the institutions of the family members for collaboration and publication purposes.

Mouse models to assess the effects of the SCN5A gene in cardiac arrhythmias have been previously reviewed [128]. Briefly, in a knockout mouse with targeted disruption of the $S C N 5 A$ gene, homozygous knockout of $S C N 5 A$ is embryonically lethal, while heterozygous ( $S C N 5 A+/-)$ mice exhibited normal 
survival, decreased atrial, atrioventricular, and ventricular conduction, and age-related deterioration of ventricular conduction due to fibrotic remodeling and redistribution of connexin 43 expression. In the same model, ventricular tachycardia occurred earlier in the right ventricular outflow tract, suggesting that arrhythmias originate in this area. Additionally, SCN5A genetic defects increase susceptibility to atrial fibrillation [128]. Langendorff-perfused $S C N 5 A+/-$ hearts exhibited a greater arrhythmic tendency in the RVOT, attributed to a combination of reduced $\mathrm{Na}_{\mathrm{V}} 1.5$ expression and increased fibrosis in the RVOT [129]. Hearts from SCN5A+/- mice have been shown to have greater incidences of bundle branch block and greater prominence of late conducting components, which were particularly evident in male or older mice and coupled with fibrosis [130]. Another study showed age-related lengthening of the P-wave and PR- and QRS-interval duration in SCN5A+/- mice, which coincided with the presence of fibrosis in the ventricular myocardium of the older mice, along with heterogeneous expression of connexin 43, upregulation of hypertrophic markers, including beta-MHC and skeletal alpha-actin, and upregulation of genes encoding Atf3 and Egr1 transcription factors [131]. Yet another study reported that both SCN5A disruption and aging were associated with decreased heart rate variability, reduced sinoatrial node automaticity, slowed sinoatrial conduction, increased collagen and fibroblast levels, and upregulated transforming growth factor- $\beta(1)$ (TGF- $\beta(1))$ and vimentin transcripts [132]. Although these studies on $S C N 5 A+/-$ mice provide valuable insights as to the potential effects of this gene, these results must be interpreted with caution, given species differences that result in differing phenotypes between species as reviewed previously $[133,134]$, and it is still unclear what the potential effects of individual variants in the SCN5A gene may be. As described above, even polymorphisms in the SCN5A gene may act as modifiers, influencing a complex pathway that ultimately results in a BrS phenotype through a series of a combination of factors.

Although studies in genetically altered mice are generally useful, it is difficult, or even impossible, to apply these sorts of models to BrS, because the genetics of BrS are not understood, making it impossible to know which genetic variant should be used to create the genetic model. Even SCN5A models are of limited use, since $S C N 5 A$ variants are not even found in the majority of patients, and also because some SCN5A variants are not even thought to be pathogenic. Therefore, it is necessary to understand both the genes and specific pathogenic variants involved in the pathogenesis of $\mathrm{BrS}$ in humans before it will be possible to create animal models using those genetic alterations. Currently, single-cell methods, such as the use of induced pluripotent stem cells, are commonly used to assess the effect of individual variants within particular genes found in patients [47]. However, findings from these studies should be interpreted with caution, since this model is limited by the functional immaturity of the cells $[135,136]$.

When possible, whole genome testing should be performed on BrS patients, and molecular autopsies should be performed on victims of sudden death. It is important to evaluate also polymorphisms, non-coding variants, and mitochondrial genes, as these may influence the BrS phenotype. In one report, mutations in mitochondrial tRNA genes were identified in Iranian BrS patients [137]. The data from whole genome testing should be compiled to create massive databases to differentiate disease-causing differences from incidental findings. Thus, further studies should be done on patients to uncover genetic mutations and to compile family segregation analysis data, so that specific candidate variants in specific genes potentially causative of $\mathrm{BrS}$ can be identified.

In conclusion, given the vast uncertainty of the role of most variants in most genes currently included in BrS diagnostic panels, caution must be taken when interpreting genetic test results. Furthermore, genetic testing currently cannot be exclusively relied upon to predict the clinical phenotype or to perform risk stratification of future arrhythmic events. BrS appears to not be a pure Mendelian disorder, but rather a common ECG pattern that results from a vast number of diverse molecular pathologies. Thus, genetic testing alone, at this point, is not sufficient to understand the complexity of this syndrome. Perhaps additional omics approaches, such as epigenomics, transcriptomics, proteomics, metabolomics, lipidomics, and glycomics, could shed light on this complex pathology. 


\section{Conclusions}

(1) The literature strongly suggests that the concept of a single causative gene with autosomal dominant inheritance may not be the case in BrS.

(2) First of all, it is clear that BrS patients can harbor both mutations and common variants, all potentially clinically meaningful, especially in the presence of multiple variants within the same individual, which can then have a combined pathological effect.

(3) Therefore, Brugada syndrome seems to be a multifactorial disease, which is affected by several loci, each of which are influenced by the environment.

(4) The influence of environmental factors for BrS clinical pictures can be both random and/or related with specific genetic variants, for example involving alcohol metabolizing enzymes.

(5) The classification of both BrS-associated mutations and common variants is not possible without a complete functional study with patch clamp and/or the voltage clamp technique.

(6) This study is aimed to understand where, when, how, and why a certain group of variants can impact cardiac channel function in a way that is necessary and sufficient to cause the manifestation of the BrS ECG.

(7) With these data it might be possible to shed a new light on the pathophysiology of the heart conduction system and on the real contribution of genetics for the BrS clinical picture.

Author Contributions: Conceptualization: M.M.M.; literature search: M.M.M., E.M., G.C.; funding acquisition: C.P.; visualization: M.M.M., E.M.; writing—original draft preparation: M.M.M.; draft revision: M.M.M., E.M.; reviewed and provided comments: M.M.M., E.M., G.C., C.P.; agreed to be co-authors on the submitted version of the paper: M.M.M., E.M., G.C., C.P. All authors have read and agreed to the published version of the manuscript.

Funding: This study was partially supported by Ricerca Corrente funding from Italian Ministry of Health to IRCCS Policlinico San Donato.

Conflicts of Interest: The authors declare no conflict of interest. The funders had no role in the design of the study; in the collection, analyses, or interpretation of data; in the writing of the manuscript, or in the decision to publish the results.

\section{References}

1. Antzelevitch, C.; Yan, G.X.; Ackerman, M.J.; Borggrefe, M.; Corrado, D.; Guo, J.; Gussak, I.; Hasdemir, C.; Horie, M.; Huikuri, H.; et al. J-Wave syndromes expert consensus conference report: Emerging concepts and gaps in knowledge. Heart Rhythm 2016, 13, e295-e324. [CrossRef] [PubMed]

2. Monasky, M.M.; Pappone, C.; Piccoli, M.; Ghiroldi, A.; Micaglio, E.; Anastasia, L. Calcium in Brugada Syndrome: Questions for Future Research. Front. Physiol. 2018, 9, 1088. [CrossRef] [PubMed]

3. Ciconte, G.; Monasky, M.M.; Vicedomini, G.; Borrelli, V.; Giannelli, L.; Pappone, C. Unusual response to ajmaline test in Brugada syndrome patient leads to extracorporeal membrane oxygenator support. Europace 2019, 21. [CrossRef] [PubMed]

4. Priori, S.G.; Wilde, A.A.; Horie, M.; Cho, Y.; Behr, E.R.; Berul, C.; Blom, N.; Brugada, J.; Chiang, C.E.; Huikuri, H.; et al. HRS/EHRA/APHRS expert consensus statement on the diagnosis and management of patients with inherited primary arrhythmia syndromes: Document endorsed by HRS, EHRA, and APHRS in 13 and by ACCF, AHA, PACES, and AEPC in June. Heart Rhythm 2013, 10, 1932-1963. [CrossRef]

5. Pappone, C.; Brugada, J.; Vicedomini, G.; Ciconte, G.; Manguso, F.; Saviano, M.; Vitale, R.; Cuko, A.; Giannelli, L.; Calovic, Z.; et al. Electrical Substrate Elimination in 135 Consecutive Patients With Brugada Syndrome. Circ. Arrhythm. Electrophysiol. 2017, 10, e005053. [CrossRef]

6. Gourraud, J.B.; Barc, J.; Thollet, A.; Le Scouarnec, S.; Le Marec, H.; Schott, J.J.; Redon, R.; Probst, V. The Brugada Syndrome: A Rare Arrhythmia Disorder with Complex Inheritance. Front. Cardiovasc. Med. 2016, 3, 9. [CrossRef]

7. Milman, A.; Andorin, A.; Postema, P.G.; Gourraud, J.B.; Sacher, F.; Mabo, P.; Kim, S.H.; Maeda, S.; Takahashi, Y.; Kamakura, T.; et al. Ethnic differences in patients with Brugada syndrome and arrhythmic events: New insights from SABRUS. Heart Rhythm 2019, 16, 1468-1474. [CrossRef] 
8. Li, X.; Sacher, F.; Kusano, K.F.; Barajas-Martinez, H.; Liu, N.; Li, Y.; Gao, Y.; Liu, T.; Shang, H.; Antzelevitch, C.; et al. Pooled Analysis of Risk Stratification of Spontaneous Type 1 Brugada ECG: Focus on the Influence of Gender and EPS. Front. Physiol. 2018, 9, 1951. [CrossRef]

9. Yuan, M.; Tian, C.; Li, X.; Yang, X.; Wang, X.; Yang, Y.; Liu, N.; Kusano, K.F.; Barajas-Martinez, H.; Hu, D.; et al. Gender Differences in Prognosis and Risk Stratification of Brugada Syndrome: A Pooled Analysis of 4,140 Patients From 24 Clinical Trials. Front. Physiol. 2018, 9, 1127. [CrossRef]

10. Nademanee, K.; Veerakul, G.; Chandanamattha, P.; Chaothawee, L.; Ariyachaipanich, A.; Jirasirirojanakorn, K.; Likittanasombat, K.; Bhuripanyo, K.; Ngarmukos, T. Prevention of ventricular fibrillation episodes in Brugada syndrome by catheter ablation over the anterior right ventricular outflow tract epicardium. Circulation 2011, 123, 1270-1279. [CrossRef]

11. Lieve, K.V.; Wilde, A.A. Inherited ion channel diseases: A brief review. Europace 2015, 17, ii1-ii6. [CrossRef]

12. Chen, Q.; Kirsch, G.E.; Zhang, D.; Brugada, R.; Brugada, J.; Brugada, P.; Potenza, D.; Moya, A.; Borggrefe, M.; Breithardt, G.; et al. Genetic basis and molecular mechanism for idiopathic ventricular fibrillation. Nature 1998, 392, 293-296. [CrossRef] [PubMed]

13. Janin, A.; Bessiere, F.; Georgescu, T.; Chanavat, V.; Chevalier, P.; Millat, G. TRPM4 mutations to cause autosomal recessive and not autosomal dominant Brugada type 1 syndrome. Eur. J. Med. Genet. 2019, 62, 103527. [CrossRef] [PubMed]

14. David, J.P.; Lisewski, U.; Crump, S.M.; Jepps, T.A.; Bocksteins, E.; Wilck, N.; Lossie, J.; Roepke, T.K.; Schmitt, N.; Abbott, G.W. Deletion in mice of X-linked, Brugada syndrome- and atrial fibrillation-associated Kcne5 augments ventricular KV currents and predisposes to ventricular arrhythmia. FASEB J. 2019, 33, 2537-2552. [CrossRef] [PubMed]

15. Cerrone, M.; Remme, C.A.; Tadros, R.; Bezzina, C.R.; Delmar, M. Beyond the One Gene-One Disease Paradigm: Complex Genetics and Pleiotropy in Inheritable Cardiac Disorders. Circulation 2019, 140, 595-610. [CrossRef] [PubMed]

16. Micaglio, E.; Monasky, M.M.; Ciconte, G.; Vicedomini, G.; Conti, M.; Mecarocci, V.; Giannelli, L.; Giordano, F.; Pollina, A.; Saviano, M.; et al. Novel SCN5A Frameshift Mutation in Brugada Syndrome Associated With Complex Arrhythmic Phenotype. Front. Genet. 2019, 10, 547. [CrossRef] [PubMed]

17. Hosseini, S.M.; Kim, R.; Udupa, S.; Costain, G.; Jobling, R.; Liston, E.; Jamal, S.M.; Szybowska, M.; Morel, C.F.; Bowdin, S.; et al. National Institutes of Health Clinical Genome Resource, C., Reappraisal of Reported Genes for Sudden Arrhythmic Death. Circulation 2018, 138, 1195-1205. [CrossRef]

18. Bezzina, C.R.; Barc, J.; Mizusawa, Y.; Remme, C.A.; Gourraud, J.B.; Simonet, F.; Verkerk, A.O.; Schwartz, P.J.; Crotti, L.; Dagradi, F.; et al. Common variants at SCN5A-SCN10A and HEY2 are associated with Brugada syndrome, a rare disease with high risk of sudden cardiac death. Nat. Genet. 2013, 45, 1044-1049. [CrossRef]

19. Monasky, M.M.; Micaglio, E.; Giachino, D.; Ciconte, G.; Giannelli, L.; Locati, E.T.; Ramondini, E.; Cotugno, R.; Vicedomini, G.; Borrelli, V.; et al. Genotype-Phenotype Correlation in a Family with Brugada Syndrome Harboring the Novel p.Gln371* Nonsense Variant in the SCN5A Gene. Int. J. Mol. Sci. 2019, $20,5522$. [CrossRef]

20. Zaklyazminskaya, E.; Dzemeshkevich, S. The role of mutations in the SCN5A gene in cardiomyopathies. Biochim. Biophys. Acta 2016, 1863, 1799-1805. [CrossRef]

21. Li, W.; Yin, L.; Shen, C.; Hu, K.; Ge, J.; Sun, A. SCN5A Variants: Association With Cardiac Disorders. Front. Physiol. 2018, 9, 1372. [CrossRef] [PubMed]

22. Risgaard, B.; Jabbari, R.; Refsgaard, L.; Holst, A.G.; Haunso, S.; Sadjadieh, A.; Winkel, B.G.; Olesen, M.S.; Tfelt-Hansen, J. High prevalence of genetic variants previously associated with Brugada syndrome in new exome data. Clin. Genet. 2013, 84, 489-495. [CrossRef] [PubMed]

23. Leong, I.U.; Stuckey, A.; Lai, D.; Skinner, J.R.; Love, D.R. Assessment of the predictive accuracy of five in silico prediction tools, alone or in combination, and two metaservers to classify long QT syndrome gene mutations. BMC Med. Genet. 2015, 16, 34. [CrossRef] [PubMed]

24. Ghouse, J.; Have, C.T.; Skov, M.W.; Andreasen, L.; Ahlberg, G.; Nielsen, J.B.; Skaaby, T.; Olesen, S.P.; Grarup, N.; Linneberg, A.; et al. Numerous Brugada syndrome-associated genetic variants have no effect on J-point elevation, syncope susceptibility, malignant cardiac arrhythmia, and all-cause mortality. Genet. Med. 2017, 19, 521-528. [CrossRef] [PubMed] 
25. Andreasen, L.; Ghouse, J.; Skov, M.W.; Have, C.T.; Ahlberg, G.; Rasmussen, P.V.; Linneberg, A.; Pedersen, O.; Platonov, P.G.; Haunso, S.; et al. Brugada Syndrome-Associated Genetic Loci Are Associated With J-Point Elevation and an Increased Risk of Cardiac Arrest. Front. Physiol. 2018, 9, 894. [CrossRef] [PubMed]

26. Pappone, C.; Ciconte, G.; Manguso, F.; Vicedomini, G.; Mecarocci, V.; Conti, M.; Giannelli, L.; Pozzi, P.; Borrelli, V.; Menicanti, L.; et al. Assessing the Malignant Ventricular Arrhythmic Substrate in Patients With Brugada Syndrome. J. Am. Coll. Cardiol. 2018, 71, 1631-1646. [CrossRef]

27. Veerman, C.C.; Podliesna, S.; Tadros, R.; Lodder, E.M.; Mengarelli, I.; de Jonge, B.; Beekman, L.; Barc, J.; Wilders, R.; Wilde, A.A.M.; et al. The Brugada Syndrome Susceptibility Gene HEY2 Modulates Cardiac Transmural Ion Channel Patterning and Electrical Heterogeneity. Circ. Res. 2017, 121, 537-548. [CrossRef]

28. Monasky, M.M.; Micaglio, E.; Ciconte, G.; Benedetti, S.; Di Resta, C.; Vicedomini, G.; Borrelli, V.; Ghiroldi, A.; Piccoli, M.; Anastasia, L.; et al. Genotype/Phenotype Relationship in a Consanguineal Family With Brugada Syndrome Harboring the R1632C Missense Variant in the SCN5A Gene. Front. Physiol. 2019, 10, 666. [CrossRef]

29. Marangoni, S.; Di Resta, C.; Rocchetti, M.; Barile, L.; Rizzetto, R.; Summa, A.; Severi, S.; Sommariva, E.; Pappone, C.; Ferrari, M.; et al. A Brugada syndrome mutation (p.S216L) and its modulation by p.H558R polymorphism: Standard and dynamic characterization. Cardiovasc. Res. 2011, 91, 60. [CrossRef]

30. Meregalli, P.G.; Wilde, A.A.; Tan, H.L. Pathophysiological mechanisms of Brugada syndrome: Depolarization disorder, repolarization disorder, or more? Cardiovasc. Res. 2005, 67, 367-378. [CrossRef]

31. Wilde, A.A.M.; Amin, A.S. Clinical Spectrum of SCN5A Mutations: Long QT Syndrome, Brugada Syndrome, and Cardiomyopathy. JACC Clin. Electrophysiol. 2018, 4, 569-579. [CrossRef] [PubMed]

32. Pappone, C.; Monasky, M.; Ciconte, G. Epicardial ablation in genetic cardiomyopathies: A new frontier. Eur. Heart J. Suppl. 2019, 21, B61-B66. [CrossRef]

33. Kyndt, F.; Probst, V.; Potet, F.; Demolombe, S.; Chevallier, J.C.; Baro, I.; Moisan, J.P.; Boisseau, P.; Schott, J.J.; Escande, D.; et al. Novel SCN5A mutation leading either to isolated cardiac conduction defect or Brugada syndrome in a large French family. Circulation 2001, 104, 3081-3086. [CrossRef]

34. Mango, R.; Luchetti, A.; Sangiuolo, R.; Ferradini, V.; Briglia, N.; Giardina, E.; Ferre, F.; Helmer Citterich, M.; Romeo, F.; Novelli, G.; et al. Next Generation Sequencing and Linkage Analysis for the Molecular Diagnosis of a Novel Overlapping Syndrome Characterized by Hypertrophic Cardiomyopathy and Typical Electrical Instability of Brugada Syndrome. Circ. J. 2016, 80, 938-949. [CrossRef] [PubMed]

35. Duthoit, G.; Fressart, V.; Hidden-Lucet, F.; Simon, F.; Kattygnarath, D.; Charron, P.; Himbert, C.; Aouate, P.; Guicheney, P.; Lecarpentier, Y.; et al. Brugada ECG pattern: A physiopathological prospective study based on clinical, electrophysiological, angiographic, and genetic findings. Front. Physiol. 2012, 3, 474. [CrossRef] [PubMed]

36. Abdelsayed, M.; Peters, C.H.; Ruben, P.C. Differential thermosensitivity in mixed syndrome cardiac sodium channel mutants. J. Physiol. 2015, 593, 4201-4223. [CrossRef]

37. Wu, Q.; Hayashi, H.; Hira, D.; Sonoda, K.; Ueshima, S.; Ohno, S.; Makiyama, T.; Terada, T.; Katsura, T.; Miura, K.; et al. Genetic variants of alcohol-metabolizing enzymes in Brugada syndrome: Insights into syncope after drinking alcohol. J. Arrhythm. 2019, 35, 752-759. [CrossRef]

38. Allegue, C.; Coll, M.; Mates, J.; Campuzano, O.; Iglesias, A.; Sobrino, B.; Brion, M.; Amigo, J.; Carracedo, A.; Brugada, P.; et al. Genetic Analysis of Arrhythmogenic Diseases in the Era of NGS: The Complexity of Clinical Decision-Making in Brugada Syndrome. PLoS ONE 2015, 10, e0133037. [CrossRef]

39. Shy, D.; Gillet, L.; Abriel, H. Cardiac sodium channel NaV1.5 distribution in myocytes via interacting proteins: The multiple pool model. Biochim. Biophys. Acta. 2013, 1833, 886-894. [CrossRef]

40. Agullo-Pascual, E.; Cerrone, M.; Delmar, M. Arrhythmogenic cardiomyopathy and Brugada syndrome: Diseases of the connexome. FEBS Lett. 2014, 588, 1322-1330. [CrossRef]

41. Garcia, J.; Tahiliani, J.; Johnson, N.M.; Aguilar, S.; Beltran, D.; Daly, A.; Decker, E.; Haverfield, E.; Herrera, B.; Murillo, L.; et al. Clinical Genetic Testing for the Cardiomyopathies and Arrhythmias: A Systematic Framework for Establishing Clinical Validity and Addressing Genotypic and Phenotypic Heterogeneity. Front. Cardiovasc. Med. 2016, 3, 20. [CrossRef] [PubMed]

42. Micaglio, E.; Monasky, M.M.; Ciconte, G.; Vicedomini, G.; Conti, M.; Mecarocci, V.; Giannelli, L.; Giordano, F.; Pollina, A.; Saviano, M.; et al. SCN5A Nonsense Mutation and NF1 Frameshift Mutation in a Family With Brugada Syndrome and Neurofibromatosis. Front. Genet. 2019, 10, 50. [CrossRef] [PubMed] 
43. Micaglio, E.; Monasky, M.M.; Resta, N.; Bagnulo, R.; Ciconte, G.; Gianelli, L.; Locati, E.T.; Vicedomini, G.; Borrelli, V.; Ghiroldi, A.; et al. Novel SCN5A p.W697X Nonsense Mutation Segregation in a Family with Brugada Syndrome. Int. J. Mol. Sci. 2019, 20, 4920. [CrossRef] [PubMed]

44. Samani, K.; Ai, T.; Towbin, J.A.; Brugada, R.; Shuraih, M.; Xi, Y.; Wu, G.; Cheng, J.; Vatta, M. A nonsense SCN5A mutation associated with Brugada-type electrocardiogram and intraventricular conduction defects. Pacing Clin. Electrophysiol. 2009, 32, 1231-1236. [CrossRef]

45. Behr, E.R.; Savio-Galimberti, E.; Barc, J.; Holst, A.G.; Petropoulou, E.; Prins, B.P.; Jabbari, J.; Torchio, M.; Berthet, M.; Mizusawa, Y.; et al. Role of common and rare variants in SCN10A: Results from the Brugada syndrome QRS locus gene discovery collaborative study. Cardiovasc. Res. 2015, 106, 520-529. [CrossRef]

46. Hu, D.; Barajas-Martinez, H.; Pfeiffer, R.; Dezi, F.; Pfeiffer, J.; Buch, T.; Betzenhauser, M.J.; Belardinelli, L.; Kahlig, K.M.; Rajamani, S.; et al. Mutations in SCN10A are responsible for a large fraction of cases of Brugada syndrome. J. Am. Coll. Cardiol. 2014, 64, 66-79. [CrossRef]

47. El-Battrawy, I.; Albers, S.; Cyganek, L.; Zhao, Z.; Lan, H.; Li, X.; Xu, Q.; Kleinsorge, M.; Huang, M.; Liao, Z.; et al. A cellular model of Brugada syndrome with SCN10A variants using human-induced pluripotent stem cell-derived cardiomyocytes. Europace 2019, 21, 1410-1421. [CrossRef]

48. Gray, B.; Hasdemir, C.; Ingles, J.; Aiba, T.; Makita, N.; Probst, V.; Wilde, A.A.M.; Newbury-Ecob, R.; Sheppard, M.N.; Semsarian, C.; et al. Lack of genotype-phenotype correlation in Brugada Syndrome and Sudden Arrhythmic Death Syndrome families with reported pathogenic SCN1B variants. Heart Rhythm 2018, 15, 1051-1057. [CrossRef]

49. Yuan, L.; Koivumaki, J.T.; Liang, B.; Lorentzen, L.G.; Tang, C.; Andersen, M.N.; Svendsen, J.H.; Tfelt-Hansen, J.; Maleckar, M.; Schmitt, N.; et al. Investigations of the Navbeta1b sodium channel subunit in human ventricle; functional characterization of the H162P Brugada syndrome mutant. Am. J. Physiol. Heart Circ. Physiol. 2014, 306, H1204-H1212. [CrossRef]

50. Lin, X.; O'Malley, H.; Chen, C.; Auerbach, D.; Foster, M.; Shekhar, A.; Zhang, M.; Coetzee, W.; Jalife, J.; Fishman, G.I.; et al. Scn1b deletion leads to increased tetrodotoxin-sensitive sodium current, altered intracellular calcium homeostasis and arrhythmias in murine hearts. J. Physiol. 2015, 593, 1389-1407. [CrossRef]

51. Riuro, H.; Beltran-Alvarez, P.; Tarradas, A.; Selga, E.; Campuzano, O.; Verges, M.; Pagans, S.; Iglesias, A.; Brugada, J.; Brugada, P.; et al. A missense mutation in the sodium channel beta2 subunit reveals SCN2B as a new candidate gene for Brugada syndrome. Hum. Mutat. 2013, 34, 961-966. [CrossRef] [PubMed]

52. Ishikawa, T.; Takahashi, N.; Ohno, S.; Sakurada, H.; Nakamura, K.; On, Y.K.; Park, J.E.; Makiyama, T.; Horie, M.; Arimura, T.; et al. Novel SCN3B mutation associated with brugada syndrome affects intracellular trafficking and function of Nav1. Circ. J. 2013, 77, 959-967. [CrossRef] [PubMed]

53. Wu, L.; Yong, S.L.; Fan, C.; Ni, Y.; Yoo, S.; Zhang, T.; Zhang, X.; Obejero-Paz, C.A.; Rho, H.J.; Ke, T.; et al. Identification of a new co-factor, MOG1, required for the full function of cardiac sodium channel Nav $1 . J$. Biol. Chem. 2008, 283, 6968-6978. [CrossRef] [PubMed]

54. Chakrabarti, S.; Wu, X.; Yang, Z.; Wu, L.; Yong, S.L.; Zhang, C.; Hu, K.; Wang, Q.K.; Chen, Q. MOG1 rescues defective trafficking of $\mathrm{Na}(\mathrm{v}) 1.5$ mutations in Brugada syndrome and sick sinus syndrome. Circ. Arrhythm. Electrophysiol. 2013, 6, 392-401. [CrossRef]

55. Olesen, M.S.; Jensen, N.F.; Holst, A.G.; Nielsen, J.B.; Tfelt-Hansen, J.; Jespersen, T.; Sajadieh, A.; Haunso, S.; Lund, J.T.; Calloe, K.; et al. A novel nonsense variant in Nav1.5 cofactor MOG1 eliminates its sodium current increasing effect and may increase the risk of arrhythmias. Can. J. Cardiol. 2011, 27, e17-e23. [CrossRef]

56. Valdivia, C.R.; Ueda, K.; Ackerman, M.J.; Makielski, J.C. GPD1L links redox state to cardiac excitability by PKC-dependent phosphorylation of the sodium channel SCN5A. Am. J. Physiol. Heart Circ. Physiol. 2009, 297, H1446-H1452. [CrossRef]

57. Cordeiro, J.M.; Marieb, M.; Pfeiffer, R.; Calloe, K.; Burashnikov, E.; Antzelevitch, C. Accelerated inactivation of the L-type calcium current due to a mutation in CACNB2b underlies Brugada syndrome. J. Mol. Cell Cardiol. 2009, 46, 695-703. [CrossRef]

58. Liu, H.; Chatel, S.; Simard, C.; Syam, N.; Salle, L.; Probst, V.; Morel, J.; Millat, G.; Lopez, M.; Abriel, H.; et al. Molecular genetics and functional anomalies in a series of 248 Brugada cases with 11 mutations in the TRPM4 channel. PLoS ONE 2013, 8, e54131. [CrossRef] 
59. Cerrone, M.; Lin, X.; Zhang, M.; Agullo-Pascual, E.; Pfenniger, A.; Chkourko Gusky, H.; Novelli, V.; Kim, C.; Tirasawadichai, T.; Judge, D.P.; et al. Missense mutations in plakophilin-2 cause sodium current deficit and associate with a Brugada syndrome phenotype. Circulation 2014, 129, 1092-1103. [CrossRef]

60. Hu, D.; Barajas-Martinez, H.; Terzic, A.; Park, S.; Pfeiffer, R.; Burashnikov, E.; Wu, Y.; Borggrefe, M.; Veltmann, C.; Schimpf, R.; et al. ABCC9 is a novel Brugada and early repolarization syndrome susceptibility gene. Int. J. Cardiol. 2014, 171, 431-442. [CrossRef]

61. Biel, S.; Aquila, M.; Hertel, B.; Berthold, A.; Neumann, T.; DiFrancesco, D.; Moroni, A.; Thiel, G.; Kauferstein, S. Mutation in $\mathrm{S} 6$ domain of HCN4 channel in patient with suspected Brugada syndrome modifies channel function. Pflugers Arch. 2016, 468, 1663-1671. [CrossRef] [PubMed]

62. Portero, V.; Wilders, R.; Casini, S.; Charpentier, F.; Verkerk, A.O.; Remme, C.A. KV4.3 Expression Modulates NaV1.5 Sodium Current. Front. Physiol. 2018, 9, 178. [CrossRef] [PubMed]

63. Giudicessi, J.R.; Ye, D.; Tester, D.J.; Crotti, L.; Mugione, A.; Nesterenko, V.V.; Albertson, R.M.; Antzelevitch, C.; Schwartz, P.J.; Ackerman, M.J. Transient outward current (I(to)) gain-of-function mutations in the KCND3-encoded Kv4.3 potassium channel and Brugada syndrome. Heart Rhythm. 2011, 8, 1024-1032. [CrossRef] [PubMed]

64. Nakajima, T.; Wu, J.; Kaneko, Y.; Ashihara, T.; Ohno, S.; Irie, T.; Ding, W.G.; Matsuura, H.; Kurabayashi, M.; Horie, M. KCNE3 T4A as the genetic basis of Brugada-pattern electrocardiogram. Circ. J. 2012, 76, 2763-2772. [CrossRef] [PubMed]

65. Ohno, S.; Zankov, D.P.; Ding, W.G.; Itoh, H.; Makiyama, T.; Doi, T.; Shizuta, S.; Hattori, T.; Miyamoto, A.; Naiki, N.; et al. KCNE5 (KCNE1L) variants are novel modulators of Brugada syndrome and idiopathic ventricular fibrillation. Circ. Arrhythm. Electrophysiol. 2011, 4, 352-361. [CrossRef] [PubMed]

66. Barajas-Martinez, H.; Hu, D.; Ferrer, T.; Onetti, C.G.; Wu, Y.; Burashnikov, E.; Boyle, M.; Surman, T.; Urrutia, J.; Veltmann, C.; et al. Molecular genetic and functional association of Brugada and early repolarization syndromes with S422L missense mutation in KCNJ. Heart Rhythm. 2012, 9, 548-555. [CrossRef]

67. Boczek, N.J.; Ye, D.; Johnson, E.K.; Wang, W.; Crotti, L.; Tester, D.J.; Dagradi, F.; Mizusawa, Y.; Torchio, M.; Alders, M.; et al. Characterization of SEMA3A-encoded semaphorin as a naturally occurring Kv4.3 protein inhibitor and its contribution to Brugada syndrome. Circ. Res. 2014, 115, 460-469. [CrossRef]

68. Mlynarova, J.; Trentin-Sonoda, M.; Gaisler da Silva, F.; Major, J.L.; Salih, M.; Carneiro-Ramos, M.S.; Tuana, B.S. SLMAP3 isoform modulates cardiac gene expression and function. PLoS ONE 2019, 14, e0214669. [CrossRef]

69. Miao, L.; Li, J.; Li, J.; Tian, X.; Lu, Y.; Hu, S.; Shieh, D.; Kanai, R.; Zhou, B.Y.; Zhou, B.; et al. Notch signaling regulates Hey2 expression in a spatiotemporal dependent manner during cardiac morphogenesis and trabecular specification. Sci. Rep. 2018, 8, 2678. [CrossRef]

70. Hartman, M.E.; Liu, Y.; Zhu, W.Z.; Chien, W.M.; Weldy, C.S.; Fishman, G.I.; Laflamme, M.A.; Chin, M.T. Myocardial deletion of transcription factor $\mathrm{CHF} 1 / \mathrm{Hey} 2$ results in altered myocyte action potential and mild conduction system expansion but does not alter conduction system function or promote spontaneous arrhythmias. FASEB J. 2014, 28, 3007-3015. [CrossRef]

71. Anderson, D.J.; Kaplan, D.I.; Bell, K.M.; Koutsis, K.; Haynes, J.M.; Mills, R.J.; Phelan, D.G.; Qian, E.L.; Leitoguinho, A.R.; Arasaratnam, D.; et al. NKX2-5 regulates human cardiomyogenesis via a HEY2 dependent transcriptional network. Nat. Commun. 2018, 9, 1373. [CrossRef] [PubMed]

72. Kapplinger, J.D.; Tester, D.J.; Alders, M.; Benito, B.; Berthet, M.; Brugada, J.; Brugada, P.; Fressart, V.; Guerchicoff, A.; Harris-Kerr, C.; et al. An international compendium of mutations in the SCN5A-encoded cardiac sodium channel in patients referred for Brugada syndrome genetic testing. Heart Rhythm. 2010, 7, 33-46. [CrossRef] [PubMed]

73. Yang, Y.; Hu, D.; Sacher, F.; Kusano, K.F.; Li, X.; Barajas-Martinez, H.; Hocini, M.; Li, Y.; Gao, Y.; Shang, H.; et al. Meta-Analysis of Risk Stratification of SCN5A With Brugada Syndrome: Is SCN5A Always a Marker of Low Risk? Front. Physiol. 2019, 10, 103. [CrossRef] [PubMed]

74. Lizotte, E.; Junttila, M.J.; Dube, M.P.; Hong, K.; Benito, B.; De Zutter, M.; Henkens, S.; Sarkozy, A.; Huikuri, H.V.; Towbin, J.; et al. Genetic modulation of brugada syndrome by a common polymorphism. J. Cardiovasc. Electrophysiol. 2009, 20, 1137-1141. [CrossRef]

75. Hoogendijk, M.G.; Opthof, T.; Postema, P.G.; Wilde, A.A.; de Bakker, J.M.; Coronel, R. The Brugada ECG pattern: A marker of channelopathy, structural heart disease, or neither? Toward a unifying mechanism of the Brugada syndrome. Circ. Arrhythm. Electrophysiol. 2010, 3, 283-290. [CrossRef] 
76. Sotoodehnia, N.; Isaacs, A.; de Bakker, P.I.; Dorr, M.; Newton-Cheh, C.; Nolte, I.M.; van der Harst, P.; Muller, M.; Eijgelsheim, M.; Alonso, A.; et al. Common variants in 22 loci are associated with QRS duration and cardiac ventricular conduction. Nat. Genet. 2010, 42, 1068-1076. [CrossRef]

77. Monasky, M.M.; Micaglio, E.; Vicedomini, G.; Locati, E.T.; Ciconte, G.; Giannelli, L.; Giordano, F.; Crisa, S.; Vecchi, M.; Borrelli, V.; et al. Comparable clinical characteristics in Brugada syndrome patients harboring SCN5A or novel SCN10A variants. Europace 2019. [CrossRef]

78. Tadros, R.; Tan, H.L.; Investigators, E.-N.; El Mathari, S.; Kors, J.A.; Postema, P.G.; Lahrouchi, N.; Beekman, L.; Radivojkov-Blagojevic, M.; Amin, A.S.; et al. Predicting cardiac electrical response to sodium-channel blockade and Brugada syndrome using polygenic risk scores. Eur. Heart J. 2019, 40, 3097-3107. [CrossRef]

79. Yeates, L.; Ingles, J.; Gray, B.; Singarayar, S.; Sy, R.W.; Semsarian, C.; Bagnall, R.D. A balanced translocation disrupting SCN5A in a family with Brugada syndrome and sudden cardiac death. Heart Rhythm 2019, 16, 231-238. [CrossRef]

80. Yagihara, N.; Watanabe, H.; Barnett, P.; Duboscq-Bidot, L.; Thomas, A.C.; Yang, P.; Ohno, S.; Hasegawa, K.; Kuwano, R.; Chatel, S.; et al. Variants in the SCN5A Promoter Associated With Various Arrhythmia Phenotypes. J. Am. Heart Assoc. 2016, 5. [CrossRef]

81. Brugada, J.; Campuzano, O.; Arbelo, E.; Sarquella-Brugada, G.; Brugada, R. Present Status of Brugada Syndrome: JACC State-of-the-Art Review. J. Am. Coll Cardiol. 2018, 72, 1046-1059. [CrossRef] [PubMed]

82. Monasky, M.M.; Ciconte, G.; Anastasia, L.; Pappone, C. Commentary: Next Generation Sequencing and Linkage Analysis for the Molecular Diagnosis of a Novel Overlapping Syndrome Characterized by Hypertrophic Cardiomyopathy and Typical Electrical Instability of Brugada Syndrome. Front. Physiol. 2017, 8, 1056. [CrossRef] [PubMed]

83. Di Resta, C.; Pietrelli, A.; Sala, S.; Della Bella, P.; De Bellis, G.; Ferrari, M.; Bordoni, R.; Benedetti, S. High-throughput genetic characterization of a cohort of Brugada syndrome patients. Hum. Mol. Genet. 2015, 24, 5828-5835. [CrossRef] [PubMed]

84. Chambers, J.C.; Zhao, J.; Terracciano, C.M.; Bezzina, C.R.; Zhang, W.; Kaba, R.; Navaratnarajah, M.; Lotlikar, A.; Sehmi, J.S.; Kooner, M.K.; et al. Genetic variation in SCN10A influences cardiac conduction. Nat. Genet. 2010, 42, 149-152. [CrossRef]

85. Qi, B.; Wei, Y.; Chen, S.; Zhou, G.; Li, H.; Xu, J.; Ding, Y.; Lu, X.; Zhao, L.; Zhang, F.; et al. Nav1.8 channels in ganglionated plexi modulate atrial fibrillation inducibility. Cardiovasc. Res. 2014, 102, 480-486. [CrossRef]

86. Watanabe, H.; Koopmann, T.T.; Le Scouarnec, S.; Yang, T.; Ingram, C.R.; Schott, J.J.; Demolombe, S.; Probst, V.; Anselme, F.; Escande, D.; et al. Sodium channel beta1 subunit mutations associated with Brugada syndrome and cardiac conduction disease in humans. J. Clin. Invest. 2008, 118, 2260-2268.

87. Hu, D.; Barajas-Martinez, H.; Medeiros-Domingo, A.; Crotti, L.; Veltmann, C.; Schimpf, R.; Urrutia, J.; Alday, A.; Casis, O.; Pfeiffer, R.; et al. A novel rare variant in SCN1Bb linked to Brugada syndrome and SIDS by combined modulation of $\mathrm{Na}(\mathrm{v}) 1.5$ and $\mathrm{K}(\mathrm{v}) 4.3$ channel currents. Heart Rhythm 2012, 9, 760-769. [CrossRef]

88. Olesen, M.S.; Holst, A.G.; Svendsen, J.H.; Haunso, S.; Tfelt-Hansen, J. SCN1Bb R214Q found in 3 patients: 1 with Brugada syndrome and 2 with lone atrial fibrillation. Heart Rhythm 2012, 9, 770-773. [CrossRef]

89. Ogawa, R.; Kishi, R.; Takagi, A.; Sakaue, I.; Takahashi, H.; Matsumoto, N.; Masuhara, K.; Nakazawa, K.; Kobayashi, S.; Miyake, F.; et al. A novel microsatellite polymorphism of sodium channel beta1-subunit gene (SCN1B) may underlie abnormal cardiac excitation manifested by coved-type ST-elevation compatible with Brugada syndrome in Japanese. Int. J. Clin. Pharmacol. Ther. 2010, 48, 109-119. [CrossRef]

90. Ricci, M.T.; Menegon, S.; Vatrano, S.; Mandrile, G.; Cerrato, N.; Carvalho, P.; De Marchi, M.; Gaita, F.; Giustetto, C.; Giachino, D.F. SCN1B gene variants in Brugada Syndrome: A study of 145 SCN5A-negative patients. Sci. Rep. 2014, 4, 6470. [CrossRef]

91. Bao, Y.; Willis, B.C.; Frasier, C.R.; Lopez-Santiago, L.F.; Lin, X.; Ramos-Mondragon, R.; Auerbach, D.S.; Chen, C.; Wang, Z.; Anumonwo, J.; et al. Scn2b Deletion in Mice Results in Ventricular and Atrial Arrhythmias. Circ. Arrhythm. Electrophysiol. 2016, 9, e003923. [CrossRef] [PubMed]

92. Hu, D.; Barajas-Martinez, H.; Burashnikov, E.; Springer, M.; Wu, Y.; Varro, A.; Pfeiffer, R.; Koopmann, T.T.; Cordeiro, J.M.; Guerchicoff, A.; et al. A mutation in the beta 3 subunit of the cardiac sodium channel associated with Brugada ECG phenotype. Circ. Cardiovasc. Genet. 2009, 2, 270-278. [CrossRef] [PubMed] 
93. Gutter, C.; Benndorf, K.; Zimmer, T. Characterization of N-terminally mutated cardiac Na(+) channels associated with long QT syndrome 3 and Brugada syndrome. Front. Physiol. 2013, 4, 153. [CrossRef] [PubMed]

94. Moreau, A.; Keller, D.I.; Huang, H.; Fressart, V.; Schmied, C.; Timour, Q.; Chahine, M. Mexiletine differentially restores the trafficking defects caused by two brugada syndrome mutations. Front. Pharmacol. 2012, 3, 62. [CrossRef] [PubMed]

95. Jagu, B.; Charpentier, F.; Toumaniantz, G. Identifying potential functional impact of mutations and polymorphisms: Linking heart failure, increased risk of arrhythmias and sudden cardiac death. Front. Physiol. 2013, 4, 254. [CrossRef] [PubMed]

96. Marionneau, C.; Abriel, H. Regulation of the cardiac Na+ channel NaV1.5 by post-translational modifications. J. Mol. Cell Cardiol. 2015, 82, 36-47. [CrossRef]

97. Chen, C.J.; Lu, T.P.; Lin, L.Y.; Liu, Y.B.; Ho, L.T.; Huang, H.C.; Lai, L.P.; Hwang, J.J.; Yeh, S.S.; Wu, C.K.; et al. Impact of Ancestral Differences and Reassessment of the Classification of Previously Reported Pathogenic Variants in Patients With Brugada Syndrome in the Genomic Era: A SADS-TW BrS Registry. Front. Genet. 2018, 9, 680. [CrossRef]

98. Brugada, R.; Campuzano, O.; Sarquella-Brugada, G.; Brugada, P.; Brugada, J.; Hong, K. Brugada Syndrome. In GeneReviews(R); Pagon, R.A., Ardinger, H.H., Wallace, S.E., Amemiya, A., Bean, L.J.H., Bird, T.D., Ledbetter, N., Mefford, H.C., Smith, R.J.H., Stephens, K., Eds.; U.S. National Library of Medicine: Rockville Pike, Bethesda, MD, USA, 2005.

99. Liu, M.; Sanyal, S.; Gao, G.; Gurung, I.S.; Zhu, X.; Gaconnet, G.; Kerchner, L.J.; Shang, L.L.; Huang, C.L.; Grace, A.; et al. Cardiac Na+ current regulation by pyridine nucleotides. Circ. Res. 2009, 105, 737-745. [CrossRef]

100. Sarquella-Brugada, G.; Cesar, S.; Zambrano, M.D.; Fernandez-Falgueras, A.; Fiol, V.; Iglesias, A.; Torres, F.; Garcia-Algar, O.; Arbelo, E.; Brugada, J.; et al. Electrocardiographic Assessment and Genetic Analysis in Neonates: A Current Topic of Discussion. Curr. Cardiol. Rev. 2019, 15, 30-37. [CrossRef]

101. Huang, L.; Tang, S.; Chen, Y.; Zhang, L.; Yin, K.; Wu, Y.; Zheng, J.; Wu, Q.; Makielski, J.C.; Cheng, J. Molecular pathological study on LRRC10 in sudden unexplained nocturnal death syndrome in the Chinese Han population. Int. J. Legal. Med. 2017, 131, 621-628. [CrossRef]

102. Nielsen, M.W.; Holst, A.G.; Olesen, S.P.; Olesen, M.S. The genetic component of Brugada syndrome. Front. Physiol. 2013, 4, 179. [CrossRef] [PubMed]

103. Juang, J.J.; Horie, M. Genetics of Brugada syndrome. J. Arrhythm. 2016, 32, 418-425. [CrossRef] [PubMed]

104. Launay, P.; Fleig, A.; Perraud, A.L.; Scharenberg, A.M.; Penner, R.; Kinet, J.P. TRPM4 is a Ca2+-activated nonselective cation channel mediating cell membrane depolarization. Cell 2002, 109, 397-407. [CrossRef]

105. Mathar, I.; Kecskes, M.; Van der Mieren, G.; Jacobs, G.; Camacho Londono, J.E.; Uhl, S.; Flockerzi, V.; Voets, T.; Freichel, M.; Nilius, B.; et al. Increased beta-adrenergic inotropy in ventricular myocardium from Trpm4-/mice. Circ. Res. 2014, 114, 283-294. [CrossRef]

106. Bianchi, B.; Ozhathil, L.C.; Medeiros-Domingo, A.; Gollob, M.H.; Abriel, H. Four TRPM4 Cation Channel Mutations Found in Cardiac Conduction Diseases Lead to Altered Protein Stability. Front. Physiol. 2018, 9 , 177. [CrossRef]

107. Demion, M.; Thireau, J.; Gueffier, M.; Finan, A.; Khoueiry, Z.; Cassan, C.; Serafini, N.; Aimond, F.; Granier, M.; Pasquie, J.L.; et al. Trpm4 gene invalidation leads to cardiac hypertrophy and electrophysiological alterations. PLOS ONE 2014, 9, e115256. [CrossRef]

108. Novelli, V.; Malkani, K.; Cerrone, M. Pleiotropic Phenotypes Associated With PKP2 Variants. Front. Cardiovasc. Med. 2018, 5, 184. [CrossRef]

109. Cerrone, M.; Montnach, J.; Lin, X.; Zhao, Y.T.; Zhang, M.; Agullo-Pascual, E.; Leo-Macias, A.; Alvarado, F.J.; Dolgalev, I.; Karathanos, T.V.; et al. Plakophilin-2 is required for transcription of genes that control calcium cycling and cardiac rhythm. Nat. Commun. 2017, 8, 106. [CrossRef]

110. Campuzano, O.; Fernandez-Falgueras, A.; Iglesias, A.; Brugada, R. Brugada Syndrome and PKP2: Evidences and uncertainties. Int. J. Cardiol. 2016, 214, 403-405. [CrossRef]

111. Antzelevitch, C.; Nof, E. Brugada syndrome: Recent advances and controversies. Curr. Cardiol. Rep. 2008, 10, 376-383. [CrossRef] 
112. Pappone, C.; Mecarocci, V.; Manguso, F.; Ciconte, G.; Vicedomini, G.; Sturla, F.; Votta, E.; Mazza, B.; Pozzi, P.; Borrelli, V.; et al. New electromechanical substrate abnormalities in high-risk patients with Brugada syndrome. Heart Rhythm 2019. [CrossRef] [PubMed]

113. Yar, S.; Monasky, M.M.; Solaro, R.J. Maladaptive modifications in myofilament proteins and triggers in the progression to heart failure and sudden death. Pflugers Arch. 2014, 466, 1189-1197. [CrossRef] [PubMed]

114. Huke, S. Linking myofilaments to sudden cardiac death: Recent advances. J. Physiol. 2017, 15, 3939-3947. [CrossRef]

115. Bezzina, C.R.; Lahrouchi, N.; Priori, S.G. Genetics of sudden cardiac death. Circ. Res. 2015, 116, $1919-1936$. [CrossRef]

116. Campuzano, O.; Sarquella-Brugada, G.; Fernandez-Falgueras, A.; Cesar, S.; Coll, M.; Mates, J.; Arbelo, E.; Perez-Serra, A.; Del Olmo, B.; Jorda, P.; et al. Genetic interpretation and clinical translation of minor genes related to Brugada syndrome. Hum. Mutat. 2019, 40, 749-764. [CrossRef] [PubMed]

117. Hennessey, J.A.; Marcou, C.A.; Wang, C.; Wei, E.Q.; Wang, C.; Tester, D.J.; Torchio, M.; Dagradi, F.; Crotti, L.; Schwartz, P.J.; et al. FGF12 is a candidate Brugada syndrome locus. Heart Rhythm 2013, 10, 1886-1894. [CrossRef] [PubMed]

118. Ishikawa, T.; Sato, A.; Marcou, C.A.; Tester, D.J.; Ackerman, M.J.; Crotti, L.; Schwartz, P.J.; On, Y.K.; Park, J.E.; Nakamura, K.; et al. A novel disease gene for Brugada syndrome: Sarcolemmal membrane-associated protein gene mutations impair intracellular trafficking of hNav1. Circ. Arrhythm. Electrophysiol. 2012, 5, 1098-1107. [CrossRef] [PubMed]

119. Valdivia, C.R.; Tester, D.J.; Rok, B.A.; Porter, C.B.; Munger, T.M.; Jahangir, A.; Makielski, J.C.; Ackerman, M.J. A trafficking defective, Brugada syndrome-causing SCN5A mutation rescued by drugs. Cardiovasc. Res. 2004, 62, 53-62. [CrossRef] [PubMed]

120. Bezzina, C.; Veldkamp, M.W.; van Den Berg, M.P.; Postma, A.V.; Rook, M.B.; Viersma, J.W.; van Langen, I.M.; Tan-Sindhunata, G.; Bink-Boelkens, M.T.; van Der Hout, A.H.; et al. A single $\mathrm{Na}(+)$ channel mutation causing both long-QT and Brugada syndromes. Circ. Res. 1999, 85, 1206-1213. [CrossRef]

121. Dumaine, R.; Towbin, J.A.; Brugada, P.; Vatta, M.; Nesterenko, D.V.; Nesterenko, V.V.; Brugada, J.; Brugada, R.; Antzelevitch, C. Ionic mechanisms responsible for the electrocardiographic phenotype of the Brugada syndrome are temperature dependent. Circ. Res. 1999, 85, 803-809. [CrossRef]

122. Mademont-Soler, I.; Pinsach-Abuin, M.L.; Riuro, H.; Mates, J.; Perez-Serra, A.; Coll, M.; Porres, J.M.; Del Olmo, B.; Iglesias, A.; Selga, E.; et al. Large Genomic Imbalances in Brugada Syndrome. PLoS ONE 2016, 11, e0163514. [CrossRef] [PubMed]

123. Sonoda, K.; Ohno, S.; Ozawa, J.; Hayano, M.; Hattori, T.; Kobori, A.; Yahata, M.; Aburadani, I.; Watanabe, S.; Matsumoto, Y.; et al. Copy Number Variations of SCN5A in Brugada Syndrome. SCN5A CNVs in BrS. Heart Rhythm 2018. [CrossRef] [PubMed]

124. Fukuyama, M.; Ohno, S.; Wang, Q.; Shirayama, T.; Itoh, H.; Horie, M. Nonsense-mediated mRNA decay due to a CACNA1C splicing mutation in a patient with Brugada syndrome. Heart Rhythm. 2014, 11, 629-634. [CrossRef]

125. Burashnikov, E.; Pfeiffer, R.; Barajas-Martinez, H.; Delpon, E.; Hu, D.; Desai, M.; Borggrefe, M.; Haissaguerre, M.; Kanter, R.; Pollevick, G.D.; et al. Mutations in the cardiac L-type calcium channel associated with inherited J-wave syndromes and sudden cardiac death. Heart Rhythm 2010, 7, 1872-1882. [CrossRef] [PubMed]

126. Abdelsayed, M.; Baruteau, A.E.; Gibbs, K.; Sanatani, S.; Krahn, A.D.; Probst, V.; Ruben, P.C. Differential calcium sensitivity in NaV 1.5 mixed syndrome mutants. J. Physiol. 2017, 595, 6165-6186. [CrossRef] [PubMed]

127. Beziau, D.M.; Barc, J.; O’Hara, T.; Le Gloan, L.; Amarouch, M.Y.; Solnon, A.; Pavin, D.; Lecointe, S.; Bouillet, P.; Gourraud, J.B.; et al. Complex Brugada syndrome inheritance in a family harbouring compound SCN5A and CACNA1C mutations. Basic. Res. Cardiol. 2014, 109, 446. [CrossRef] [PubMed]

128. Derangeon, M.; Montnach, J.; Baro, I.; Charpentier, F. Mouse Models of SCN5A-Related Cardiac Arrhythmias. Front. Physiol. 2012, 3, 210. [CrossRef]

129. Zhang, Y.; Guzadhur, L.; Jeevaratnam, K.; Salvage, S.C.; Matthews, G.D.; Lammers, W.J.; Lei, M.; Huang, C.L.; Fraser, J.A. Arrhythmic substrate, slowed propagation and increased dispersion in conduction direction in the right ventricular outflow tract of murine Scn5a+/- hearts. Acta Physiol. (Oxf) 2014, 211, 559-573. [CrossRef] 
130. Jeevaratnam, K.; Rewbury, R.; Zhang, Y.; Guzadhur, L.; Grace, A.A.; Lei, M.; Huang, C.L. Frequency distribution analysis of activation times and regional fibrosis in murine Scn5a+/- hearts: The effects of ageing and sex. Mech. Ageing Dev. 2012, 133, 591-599. [CrossRef]

131. Royer, A.; van Veen, T.A.; Le Bouter, S.; Marionneau, C.; Griol-Charhbili, V.; Leoni, A.L.; Steenman, M.; van Rijen, H.V.; Demolombe, S.; Goddard, C.A.; et al. Mouse model of SCN5A-linked hereditary Lenegre's disease: Age-related conduction slowing and myocardial fibrosis. Circulation 2005, 111, 1738-1746. [CrossRef]

132. Hao, X.; Zhang, Y.; Zhang, X.; Nirmalan, M.; Davies, L.; Konstantinou, D.; Yin, F.; Dobrzynski, H.; Wang, X.; Grace, A.; et al. TGF-beta1-mediated fibrosis and ion channel remodeling are key mechanisms in producing the sinus node dysfunction associated with SCN5A deficiency and aging. Circ. Arrhythm. Electrophysiol. 2011, 4, 397-406. [CrossRef] [PubMed]

133. Milani-Nejad, N.; Janssen, P.M. Small and large animal models in cardiac contraction research: Advantages and disadvantages. Pharmacol. Ther. 2014, 141, 235-249. [CrossRef] [PubMed]

134. Janssen, P.M.; Biesiadecki, B.J.; Ziolo, M.T.; Davis, J.P. The Need for Speed: Mice, Men, and Myocardial Kinetic Reserve. Circ. Res. 2016, 119, 418-421. [CrossRef] [PubMed]

135. Koivumaki, J.T.; Naumenko, N.; Tuomainen, T.; Takalo, J.; Oksanen, M.; Puttonen, K.A.; Lehtonen, S.; Kuusisto, J.; Laakso, M.; Koistinaho, J.; et al. Structural Immaturity of Human iPSC-Derived Cardiomyocytes: In Silico Investigation of Effects on Function and Disease Modeling. Front. Physiol. 2018, 9, 80. [CrossRef] [PubMed]

136. Hoekstra, M.; Mummery, C.L.; Wilde, A.A.; Bezzina, C.R.; Verkerk, A.O. Induced pluripotent stem cell derived cardiomyocytes as models for cardiac arrhythmias. Front. Physiol. 2012, 3, 346. [CrossRef] [PubMed]

137. Tafti, M.F.; Khatami, M.; Rezaei, S.; Heidari, M.M.; Hadadzadeh, M. Novel and heteroplasmic mutations in mitochondrial tRNA genes in Brugada syndrome. Cardiol. J. 2018, 25, 113-119. [CrossRef]

(C) 2020 by the authors. Licensee MDPI, Basel, Switzerland. This article is an open access article distributed under the terms and conditions of the Creative Commons Attribution (CC BY) license (http://creativecommons.org/licenses/by/4.0/). 